FACTA UNIVERSITATIS

Series: Teaching, Learning and Teacher Education Vol. 1, No 2, 2017, pp. 185 - 197

https://doi.org/10.22190/FUTLTE1702185S

Review article

\title{
ELECTRONIC EVALUATION IN TEACHING CLASS: ASSESSMENT VALUE OF EDUCATIONAL SOFTWARE
}

UDC 37.02:004

\author{
Dragana Stanojević ${ }^{1}$, Zoran Stanković ${ }^{2}$ Jelena Maksimović ${ }^{2}$ \\ ${ }^{1}$ Pedagogical Faculty in Vranje, University of Niš, Serbia \\ ${ }^{2}$ Faculty of Philosophy in Niš, Department of Pedagogy, University of Niš, Serbia
}

\begin{abstract}
As a result of the expansion of informatics era, in the last decade is a noticeable focus on the development and application of ICT in education, which, thanks to its rapid development marks the era of electronic education. The goal of electronic education is actually a modernization of the teaching process, which will enable teachers the reduction of teaching duties, simplify preparation and teaching and testing students' knowledge, which with the electronic platform is becoming an important component of a multimedia approach to teaching. The main objective of this work is to draw attention to the general pedagogical expert and scientific public and to point to a wider range of options provided by this type of evaluation in the educational process, and it is already at the level of teaching classroom. In this sense, in the paper, in addition to theoretical considerations are presented and acquired experience from practice ${ }^{l}$, resulting from implementation assessments potential of created educational software, as well as the experience of using modern educational technology.
\end{abstract}

Key words: computer classes, educational software, knowledge tests, electronic grading, electronic evaluation

\section{INTRODUCTION}

Entering the XXI century we have witnessed the increasingly frequent appeals for modernization and radical changes in the implementation of the teaching process, in order to overcome the weaknesses of still dominant traditional (frontal) classes. While didactics continuously gives its theoretical contribution, methodological (practical) implementation is not even on satisfactory level. It's all about individual cases of research

Received December 30, 2017/Accepted January 10, 2017

Corresponding author: Dragana Stanojević

Pedagogical Faculty in Vranje, University of Niš, Partizanska 14, 17500 Vranje, Serbia

Phone: +381 17 431-960 •E-mail: dstanojevic@ucfak.ni.ac.rs

${ }^{1}$ Paper represents a part of realized pedagogical (didactical) experiment called Individualization of methodical teaching model using the educational software. 
and offers of methodical solutions for the mentioned issues. In the pedagogical literature, with issues of creating didactic software, multimedia teaching strategies and electronic evaluation dealt many relevant authors (Mandić, 2004; Matijević, 2005; Matijević \& Topolovčan, 2017; Nadrljanski \& Nadrljanski, 2008; Radosav, 2005), giving a significant and primarily theoretical scientific basis.To this days, there is still a great deficiency in the offer of concrete practical and methodical solutions of the mentioned problem. On this occasion, we intend to transfer our own experience from practice and to point out the importance and the possibility of using electronic methods of evaluation more at the level of classroom teaching.

One of the valid solutions could certainly be a new methodological model (multimedia strategy), which essence is reflected in the integration of individual teaching systems in an Educational Software (Fig. 1), and putting them into the function of individualization of teaching (Stanković, 2005; Stanković \& Blažić, 2015).

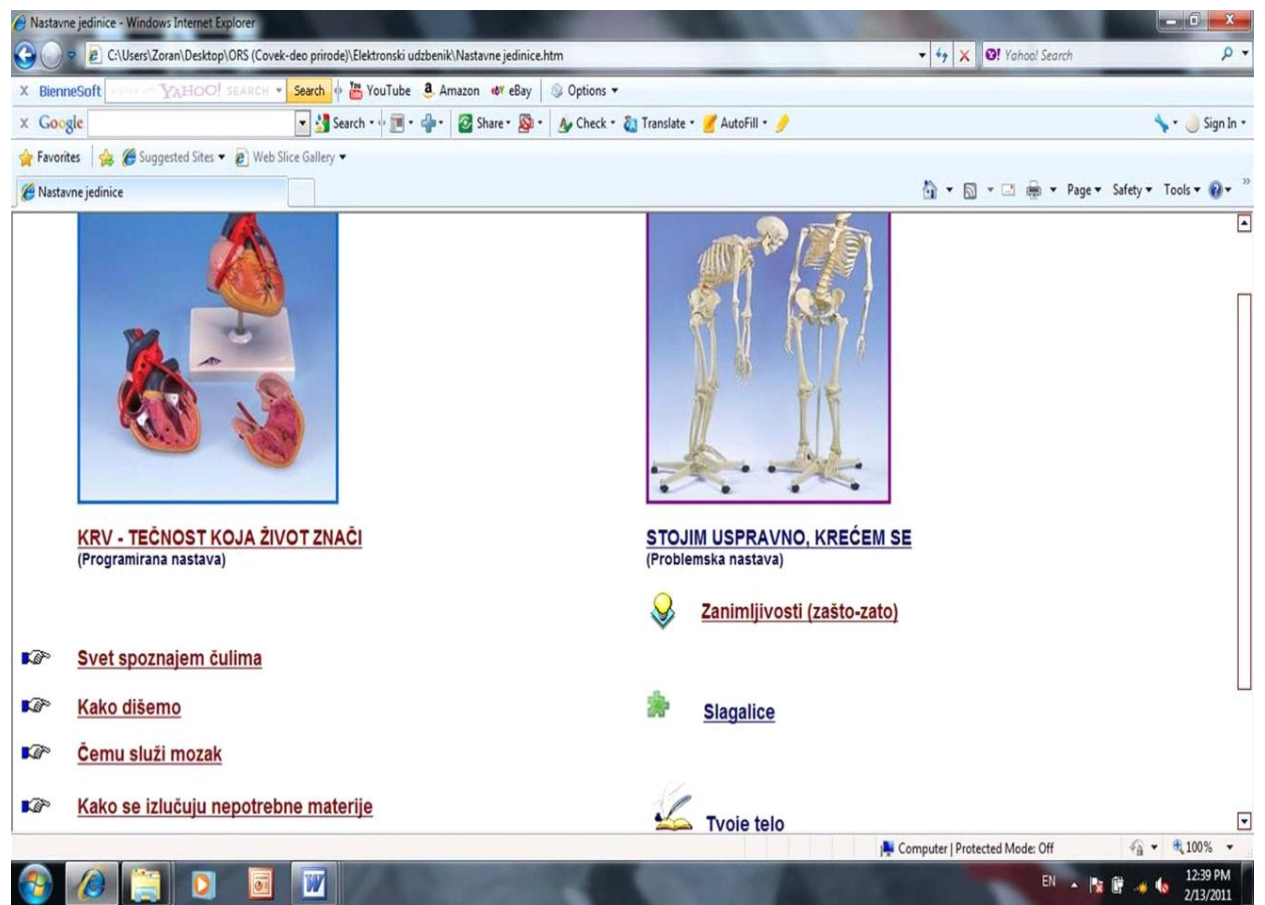

Fig. 1 Insert from ECS "man - part of nature": display of teaching units

In using this most modern kind of strategies of computer teaching and learning, one of the most important phase is certainly verification of students' achievements through the electronic evaluation. In that context, for this occasion we decided to convey positive and empirically verified experiences in that field, and show certain methodological and assessment possibilities and implications in the preparation and creation of verification phase in the Educational Computer Software (ECS), using an available application software WBTExpress. 


\section{THEORETICAL ORIENTATION}

\subsection{Computer teaching and learning}

From the beginning of programmed learning and teaching, work has been closely associated with the operation on the mechanical devices that makes learning easier, as the result of that, the name of this phenomenon from the beginning included machines for learning. According to the Pedagogical lexicon (1996), those are the technical devices that can relatively independently perform three essential phases of teaching as follows: exposure or display of new material; activation of students with given material and collaboration, i.e. obtaining feedback of the quality of students responses, and their learning.

At the beginning, there was a polemic about their importance and has been considered for the long time that technical solutions have secondary importance and that their role is limited to a more rational use of the attainment that studies of the learning process has made. When it is been analyzed from the current perspective, we can agree that this attitudes had the foundation back then, because the former programs were manufactured with no adjustment for the use in the machines and were published in the form of printed materials. However, today with all the massive use of computers and special didactical and methodical designing of educational software, computers strongly affect the overcoming of "mechanization" of learning and increasingly contribute to the new organization of the teaching process. About the connection between programmed models of work and computer learning testifies also the fact of the existence of preferred methods in teaching process, formulated in the field of cybernetic didactics, namely:

- Method of computerization with teaching algorithmics (in semi-programmed teaching in which working is without a computer, It has used the method of the didactical algorithmics);

- Auto-abstraction method is used (in the determination class, repetition, and practice) in the process of individualized teaching of cybernetic direction, as an example in the programmed learning in schools or outside of it;

- Method of (electronic) evaluation with the qualification and quantification of students' achievements in teaching and learning process;

- Auto- correction method in the process of programmed learning (computerassisted or teacher's).

Which methods and teaching aids will be used for achieving the placed goals, inter alia, will depend of the correct identification and analysis of the four constants: intentionality, themes (content), methods and devices. On the basis of these constants, teacher's need to know what and how wants to achieve it, so he goes to the field of decision-making. Methodology and its models must follow the innovation and adapt to each of them. The goal of each model is the highest possible quality of students' knowledge. It should be noted that the learning process is truly inseparable relationship between teachers and students, as an example teaching and learning. Nowadays, that process is almost inconceivable without the use of computer learning. Powerfully computers have become an indispensable tool that enables empirical verification of theoretical ideas and creation of the projects which, more or less, correspond to human cognitive functions.

This question is the subject of many authors, both foreign and domestic. There are many definitions, but in essence, they are reduced to the idea of educational software that means "intellectual technology" that includes computer programs that can be used in the teaching process, programs that assist and guide individual learning. Also, ECS includes 
programming languages, software tools, certain organization of teaching and learning, and contains a variety of educational programs aimed at students of different ages, based on logic and pedagogy" (Nadrljanski \& Nadrljanski, 2008, p. 169).

In some developed countries (USA, England, Germany, Switzerland ...) there is educational computer software that is not directed to school, but is intended solely for the individual work and learning. Also, there is software that is intended only for different types and contents of functional education (seminars, courses of certain fields, training for a specific job, etc.).

The main role of educational software as an advanced interactive media is to facilitate, accelerate and create preconditions: the process of students' learning; understanding of educational content; the activity of the students in the learning process; mastering the learning process at all levels, starting from the knowledge of the basic facts about the processes, phenomena and events, through their understanding with thought-processing, to the practical application of knowledge.

Characteristics of multimedia applications, represented in educational software, that enhance the educational process are as follows: visual presentation of knowledge; a broad base of available knowledge; indices; research (students are researchers which with the help of "guides", "tours", etc., which are an orientation in mastering of the material to get the needed information); student's individual style (emphasis on internal insight, discovery, exploration, conceptual knowledge and understanding of mutual relations); simulation (except for navigational interaction students can use simulation, various intellectual tools, games, such as "what if" with the material such us "Why-so" etc.); realization of communications networks, through which the group can exercise simulations, create opportunities for discussion and exchange of views, opinions, and informations.

The most important value of educational software is that with its help a multimedia approach to teaching is achieving. According to the Pedagogical lexicon (1996, p. 305) "multimedia approach (system) in teaching implies teaching based on the use of modern educational technology, all or the most contemporary sources and carriers of educational information. It's understood also as the integrative connection of a combination of different media and ways of their implementation, based on the didactical requirements, in order to overcome the learning process directed towards a specific goal. "Both allows far-reaching objectification of different situations of teaching and learning, as well as taking over the function of teaching, whose design belongs to the teacher or group of students. Multimedia Package (lat. Multus - many) means a collection of teaching media - resources for a multimedia approach in education, which allows students to individually learn and self-educate. Various media as sources of knowledge are given in the package (all in one place) for easier and more rational teaching, with the realization of the principle of obviousness and student activities. Their functional and technical integration allows students a variety of approaches in learning of teaching materials, which increases the efficiency and optimality of the teaching and learning process.

This software helps the student independently or with the help of teachers, presents teaching content, giving individually or bundled image, sound, drawing, animation, and others. They can require from the students to solve problems, ask questions and continue the conversation. They are able to observe the work of the student, to help him, to evaluate what he does, give feedback and provide favorable conditions for the acceleration. On all of that, we should add a great motivation for students' work, the ability to progress at their own pace in learning, as well as permanent intellectual activity during work. 
With using of educational materials in electronic form in teaching not only we have a possibility of new pedagogical paradigms, but it imposes a new form of technical cooperation between the teachers themselves. The need and desire to design a material suitable for digital presentation for each subject and for all generations, will expel individual authors and replace them with creative groups. Once created electronic educational content is easily adjusted and upgraded (in the case of any upcoming reform) compared to the classic textbook (Writing scratch and by individuals). The ability for this project is being built through the simultaneous and parallel development of didacticmethodological and ICT competencies of teachers and the broader pedagogical repertoire.

\subsection{Electronic evaluation}

Evaluation (franc. Évoluer; eng. Evaluation; germ. Wertung) is an integral part of the process of learning and teaching. It involves determining of the relative value of something according to the already adopted standards. In pedagogy and didactics it's been related to the assessment of pupils' development towards the goals of the curriculum. The main purpose is to evaluate the quality of knowledge of students (or teachers' work) to be able to intervene in a timely manner in terms of correcting possible errors in the process of acquiring knowledge (or teachers' work). In the basis of the structure of the object of studying docimology is an evaluation as a form of evaluation, which implies "the process of monitoring of educational work and students' development and determines the level that students have achieved, according to the established rules" (Gojkov, 2003, p. 16). There are two basic functions of the evaluation system. One is summative, which is reflected in the certification or issuing certificates of successful completion of a certain level of education, while formative, as well as other functions of assessment, implies giving feedback on the progress, quality and results of the educational process, in order to enter corrections on time, which would lead to better outcomes (National Education Council, 2011).

Evaluation of educational achievements of students is an integral part of the teaching process, which is often labeled as the most important and most sensitive aspect of the evaluation system. However, the evaluation process, as institutionalized and legally regulated pedagogical activity, is determined as a basic right and duty of every teacher. It's been pointed out by Kuzmanović \& Babić (2011), evaluation is considered as an integral part of the educational process, which is directly related to curricula, teaching practices, and educational outcomes.

The evaluation system, of the educational process, requires continuous monitoring and recording of all relevant data, systemic checking and objective assessment of student achievement in the educational cycle in which they are located. According to Hunt et al. (Hunt et al., 2002), assessment of knowledge, as a crucial element of the learning process, provides very useful information about the extent in which has been achieved a pre-set educational standards.

Electronic technology is now of vital importance in ensuring of pluralism of educational assessment skills both in the classroom as well as in situations of informal and non-formal education. With dynamic multimedia customers interactions, electronic evaluation significantly extends the capabilities of the testing and evaluation of students' knowledge beyond the boundaries of traditional tests. In line with this and in other technological innovations, electronic work platforms offer the opportunity for a high-quality formative evaluation that in several dimensions overlaps with the activities and the goals of the course, making an important contribution to teaching based on e-technology. 


\subsection{Advantages and disadvantages of the electronic evaluation}

The modern approach to e-learning allows to the learning process to be more dynamic, and of course adapted to the educational needs and interests of students. Modern models of teaching, which in its structure include the use of educational technology, engage higher cognitive processes (analysis, synthesis, a generalization ...) of students who have been neglected with the traditional mode. Apart from the individualized approaches, differentiation of teaching content, the benefits of e-learning overcome the boundaries of teaching, leaving space for students in the age of digitization to master the techniques and learning strategies that will gradually but with great certainty get closer to their individual educational potential. In that context, one of the major advantages of e-learning is a multimedia platform for checking and testing of knowledge, which in many countries is an unavoidable aspect of the modern organization of teaching.

Although electronic evaluation has its drawbacks (minimal contact with students, the lack of necessary information about individual students' abilities, financial expenditures procurement, maintenance and upgrade of the technical base, lack of IT competence of a good part of the teaching staff), on the other side, there is a much longer list of advantages of this modern vision of evaluation. Let us mention some of the more relevant:

- successfully overcome the problems "of campaign" evaluation;

- absolutely uniform criteria of evaluation of the work results (no impact of "severe" and "mild" and "personal problems" of teachers);

- timely feedback on the performance of work;

- timely and accurate locating of errors (providing the possibility of immediate response to fix them);

- wide optimization of teaching - rationalization of time (more time that can be used constructively to correct possible errors, for the operationalization of the acquired knowledge, acceleration, etc.);

- Disburden of the teacher (in a relatively short time teacher receives a full and clear picture of the achievements of each individual, which leads to relaxation and focus on error correction, planning the next steps in the implementation of teaching material, etc.).

As an integral part of the evaluation, we have the phenomenon of self-evaluation (selfevaluation and the creation of self-image and personality of the students in general) which provides an additional positive dimension, from the aspect of flexibility or responsibility and democratization of the educational process. Self-evaluation and timely feedback within it, enable immediate intervention on fixing errors (while the material is "hot"), and on the other side, if everything is done correctly, it is an additional stimulus for the further progress in the process of active knowledge acquisition.

At the end of this segment of the labor, we are also pointing at the possibility of personal creating of complete e-test and the required assessment apparatus, by teachers who have basic computer knowledge. This feature is used in practice if a teacher is not satisfied with the evaluation parameters of found software solutions. In fact, although many available solutions evaluate standard parameters, and are often in a function of individualization of teaching, but not the individualization of assessment, which involves continuous monitoring, individualized database, and a wider evaluation apparatus.

- Assessment opportunities ESC (practice example)

On the following pages, we will keep on images of certain examples which are the reflection of capability (variants) to create certain types of tasks in the knowledge test. 


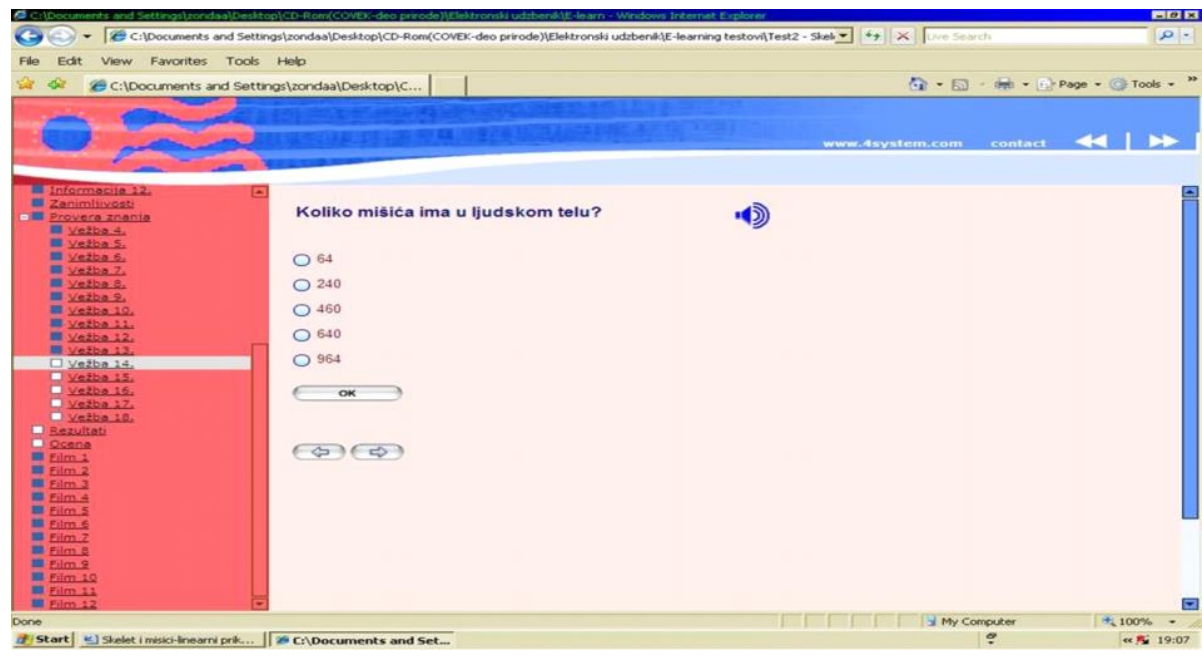

Fig. 2 Insert from ESC - the first variant of the multiple choice task

Basic and the lowest variant of the types of tasks are the tasks of an alternative type of choice (yes / no, true / false, etc.). It is evident that this type of task is easy to create with the software, but we did not choose their use, knowing the age and intellectual structure of students of primary school (they are more appropriate for students in I class). As an initial, the lightest variant of the reproduction we used a multiple-choice type of task (Fig. 2). Still, in the initial instruction, it's been pointed to the students that they will have questions, in which there are circles, mark one answer, while those in which are boxes they will be able to select and mark the greater number of correct answers (Fig. 3). Of course, this means timely feedback supported by auditory components.

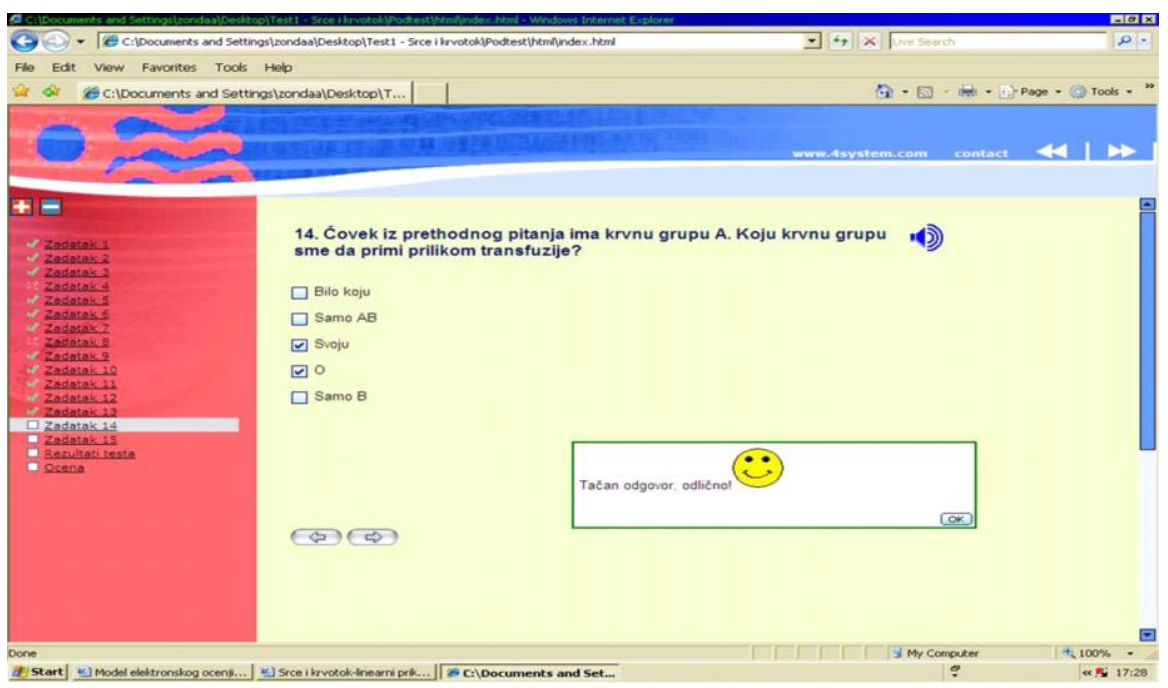

Fig. 3 Insert from ESC - another variation of multiple-choice task 
Another type of creating questions that software allows are tasks of recalling and backfill, so called tasks of short responses (Fig. 4). Here we should mention the possibility, that the program allows creating tasks in their native language, as well as that we can indicate various options in which the software will register the correct answers. This is primarily related to the proper use of grammar and orthographic use of words and sentences (why it is very suitable preparation and for the needs of teaching mother language), but also to possible typographical errors and mistakes during the use of a keyboard. This feature, we also predicted by having in mind primarily specificity of ours, and all groups of Slovenian language. We though that it was illusory not to admit student's response if it is not properly configured code character of the keyboard (instead of letters č, ž, š, computer reflects c, z, s, etc.).

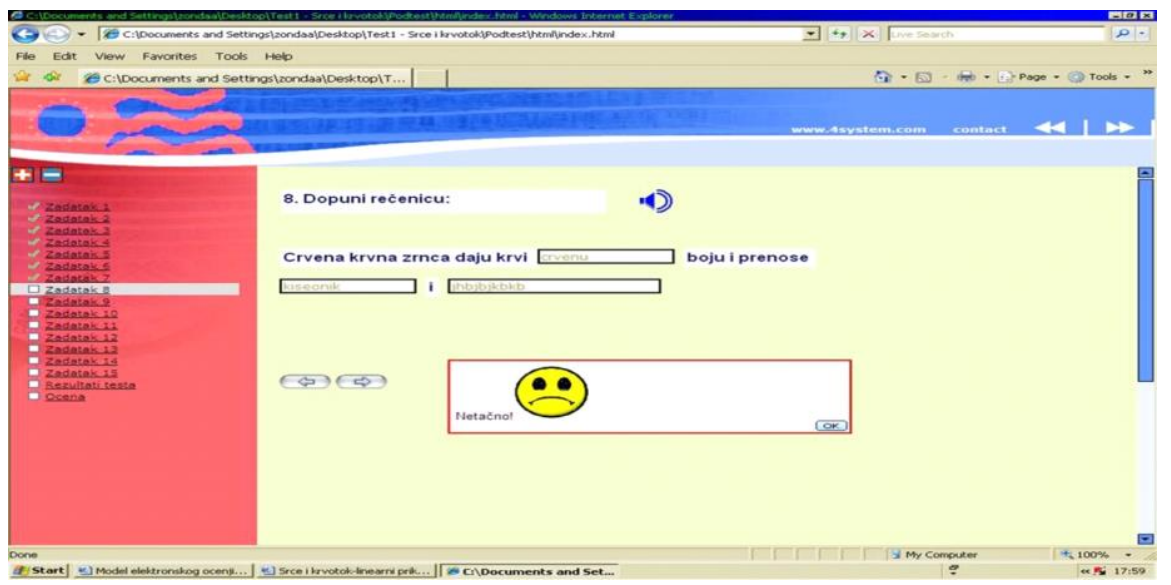

Fig. 4 Insert from ESC - task variant type of replenishment

The special convenience that ESC and multimedia provide (compared to the conventional vision of testing students) is that recorded videos, animations and simulations are the main source and motivation for the construction of the questions. (Fig. 5).

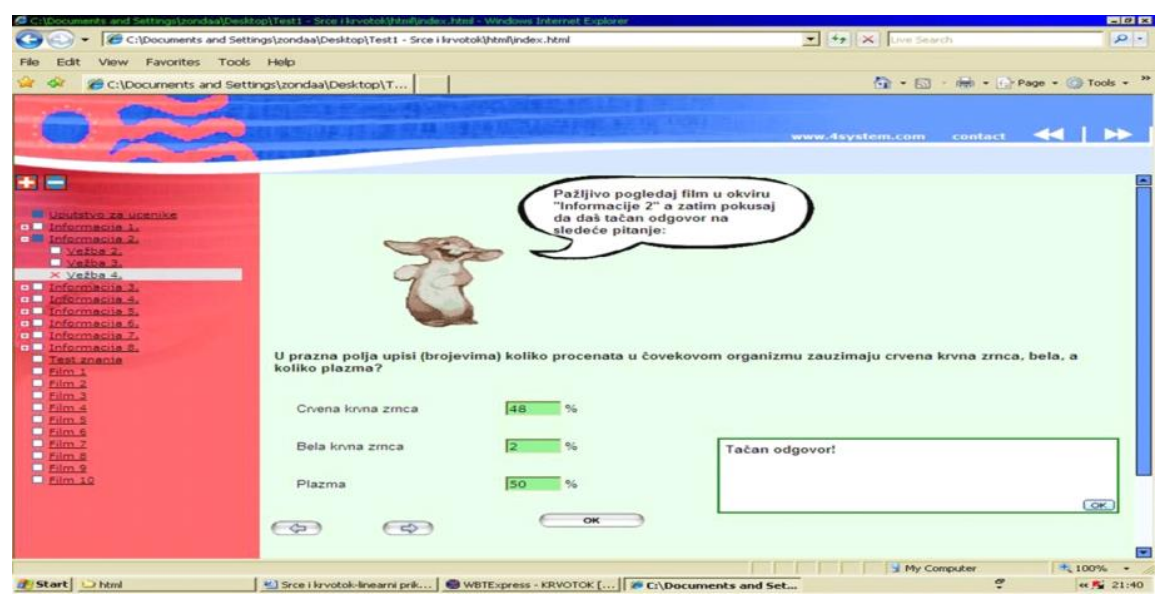

Fig. 5 Insert from ESC - task variant type of replenishment supported by multimedia 
Another possibility developing of a type of coupling- joining tasks (Fig. 6), whose essence is in spotting and attributing connections to the certain terms. They can be used in several varieties, of which we choose (because of the creativity of the program and interesting approach) model of proper linking of terms and statements (correctly merge or filling of the left and right sides, coating by using a "mouse" of the computer). This variant is recognized in tests such as "pen-paper" in which by drawing a line we connect adequate elements.

Anyhow, it should be pointed here to the software's ability of constantly showing the algorithm on the left side of the screen of work performed by continuously monitoring and recording (check-in) students' responses with green and red color. After completion of work, we are crossing to the page which gives an overview of the results of the done test of knowledge.

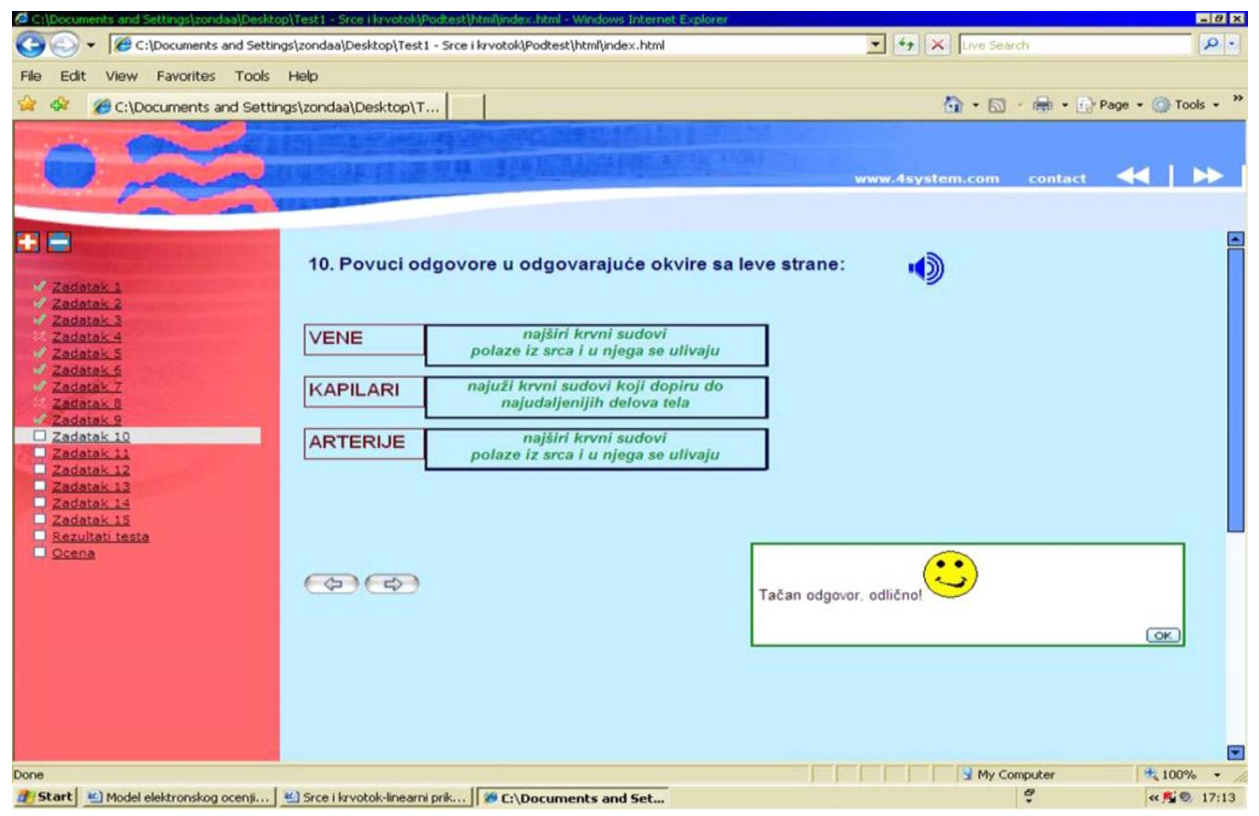

Fig. 6 Insert from ESC - task variant type of correlating (joining)

In this segment of evaluation, there was an additional dilemma. Although the program WBTExpress contains the correct assessment apparatus (username, start, end and the total working time in the test, the number of points, the percentage of performance, a detailed overview of each by all the made questions) it is not provided and there is no success achievement expressed in the form of specific assessments (Fig.7). This is expressed in the program only through a descriptive status ("passed" - passed, passed, or "failed" - not passed, failed), or with the percentage report and score. Although the results are presented in the English language, there is a possibility of correction - a change in the program, for the purpose of reporting in the native language. 


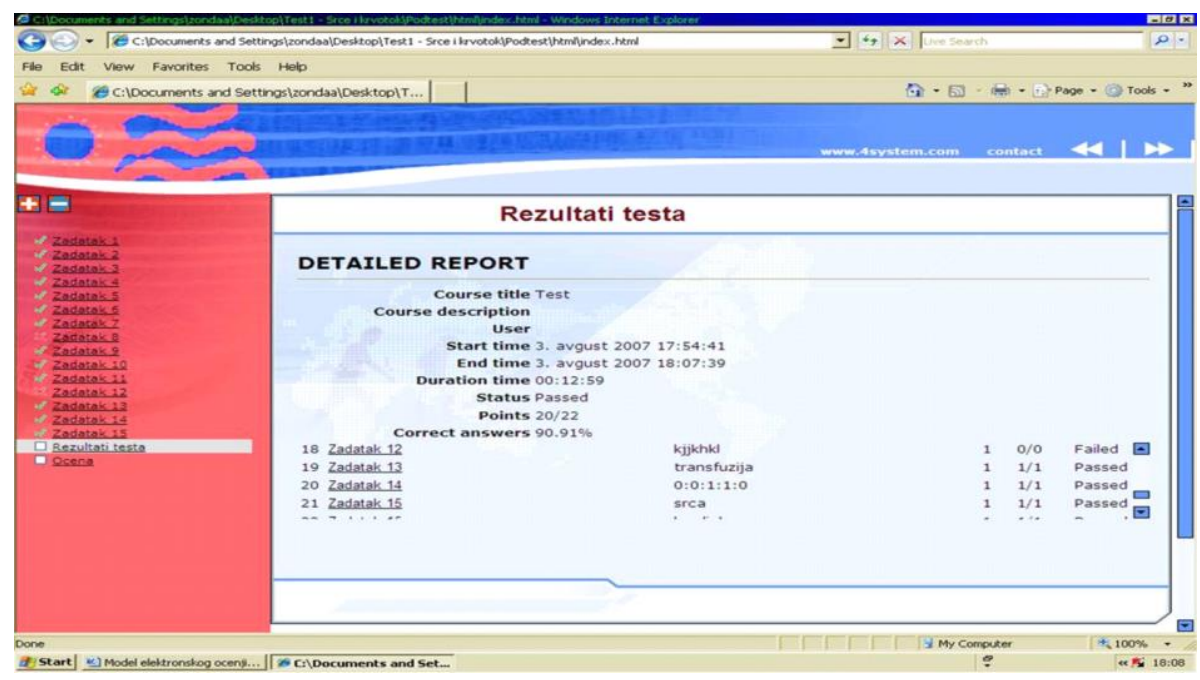

Fig. 7 Insert from ESC - reviewal of the final knowledge test results

All listed data is very useful for keeping assessment documentation by the teacher, and he can construct mark based on the displayed parameters, but the student remains deprived for the segment that interested him the most. In finding ways to provide students with the satisfaction in this field, it may be formed "grading scheme" on the basis of which it will be able to carry out the final assessment, considering that students of this age have built the term of percent (Fig. 8).

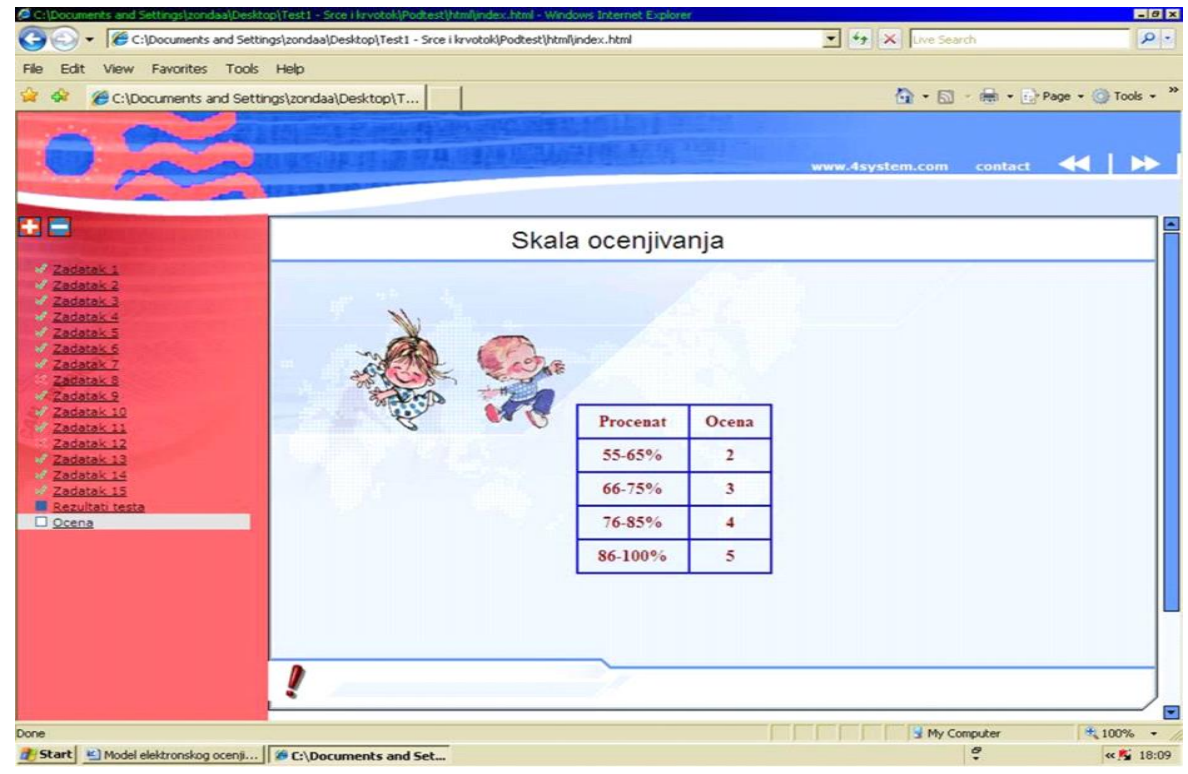

Fig. 8 Insert from ESC - shew of the grading scale 
This question further intrigued us to check whether there are available programs with the ability to display precise assessment data. We came to the conclusion that one of the adequate programs could be for exampleVisualBasic (Fig. 9 and 10).

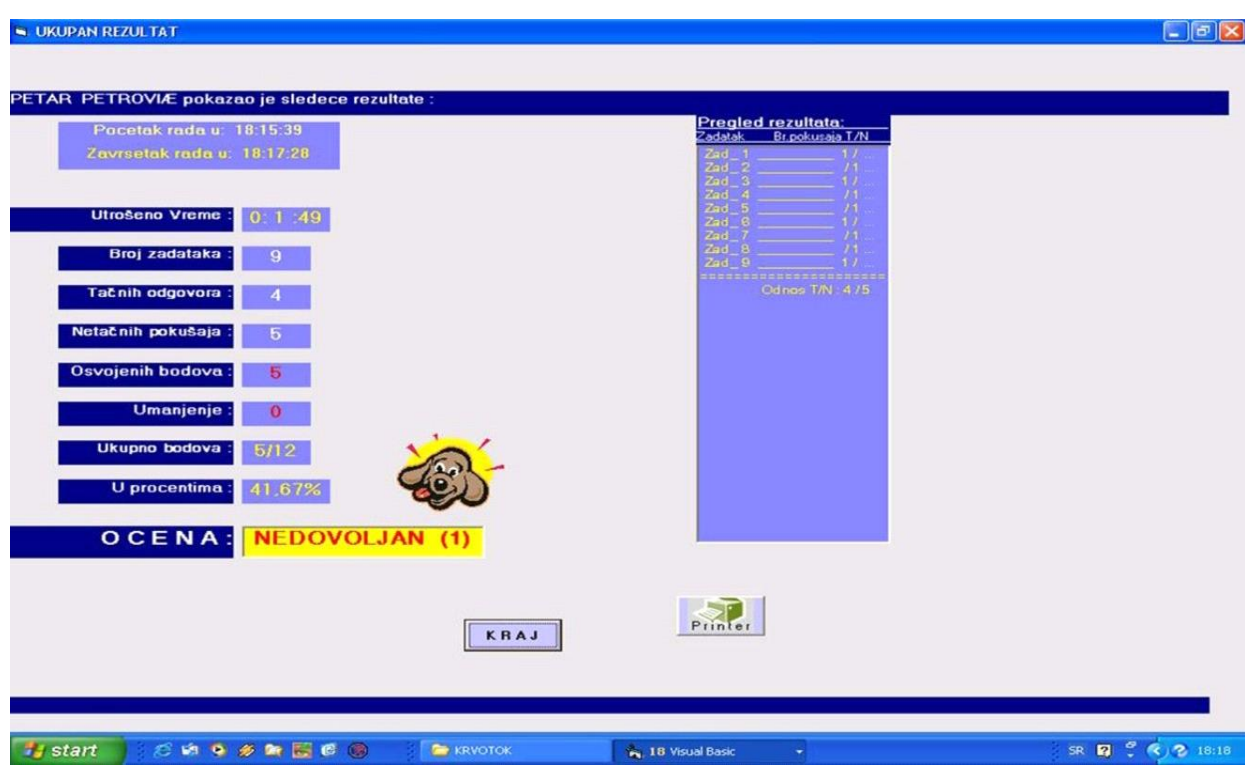

Fig. 9 Insert from ESC created in a Visual Basic (VB)

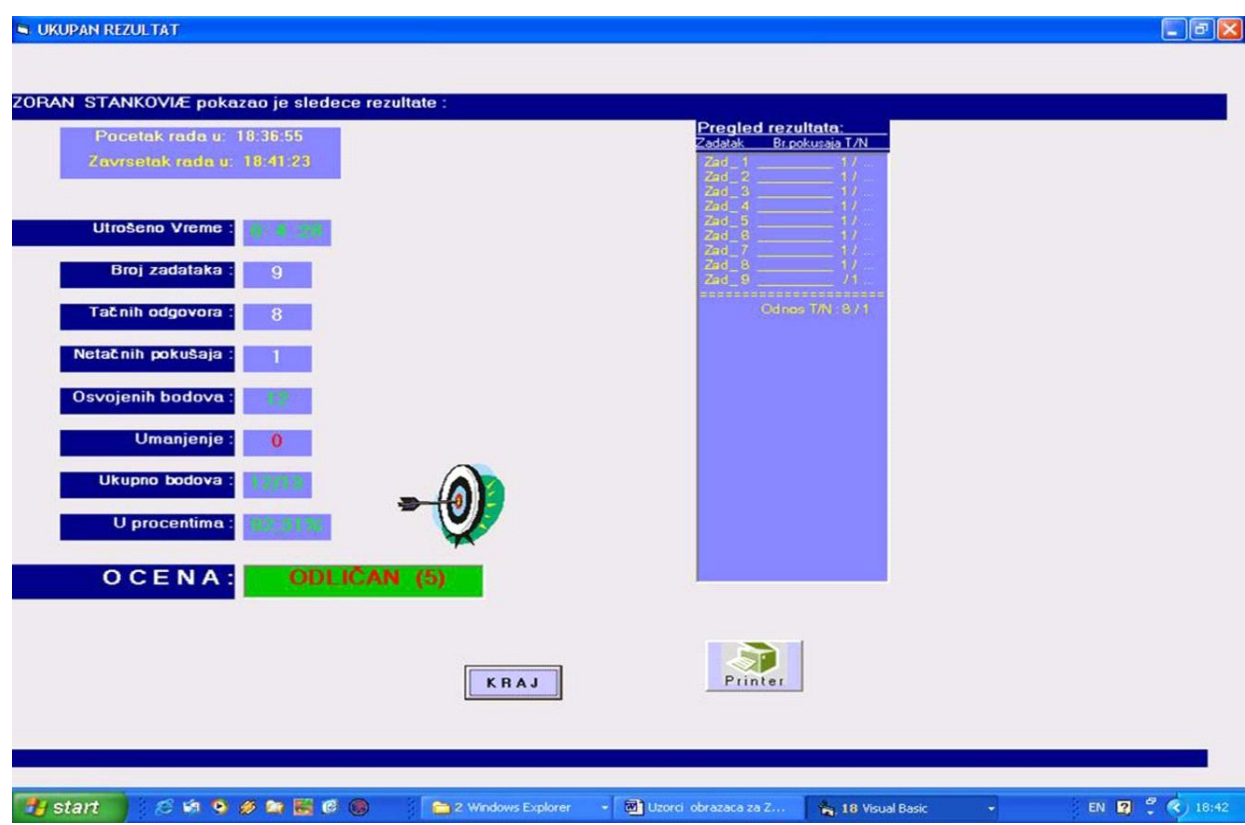

Fig. 10 Insert from ESC in VB; parameters such as achieved excellent success 
Another advantage provided by the Visual Basic program is a possibility of creating a database which will archive and store data of every student in a longer period of time, which helps teacher in comparing the efforts after a certain period, dedication, progress, etc. (In relation to the previous period), which is one of the main requirements for the implementation of individualization in the evaluation.

\section{CONCLUSION}

One of the valid solutions to overcome weaknesses in the teaching process is certainly a multimedia approach of teaching by using of adequate educational software, which by its linearity and an abundance of information is "inexhaustible food" for each student. This puts the question of where in all of this is the teacher? In not so distant past, individuals have claimed that he would soon be marginalized, and even unnecessary in the teaching process. This is only apparent "optical illusion" because it is exactly the opposite. For all of the above, he will be credited just competent, methodically qualified, modern and creative teacher. He's the one who is arranging everything, collecting supplies, who is programming (material and software) and implementing it in order to individualization of the teaching process. Because he is not exposed (as in classical teaching) only proves that created educational software just allows him to change the position and roles (to be the creator, director, and moderator), which truly fulfills the highest requirements and standards of the most advanced classes. All this shows us that the school has to turn more to the modern educational technology, to prepare teachers for its use and create a situation in which the computer will have in school that function as it has in other areas of life.

Digitalization of classical school evaluation, come up with some innovations which previously could not even be imagine. With electronic evaluation, the educational process becomes more efficient, optimal, and the reduction of teachers' obligations (records about held classes and extracurricular activities, school assignments, recording grades, absences, the subject of written assignments, etc.), allows the teacher to devote more time to work on identifying potential of students, professional development and continuous innovation of the teaching process.

\section{REFERENCES}

Gojkov, G. (2003). Dokimologija [Dokimology]. Vršac: Viša škola za obrazovanje vaspitača.

Hunt, N., Hughes, J. \& Rowe, G. (2002). Formative automated computer testing (FACT), Br. J. Educ. Technol., 33(5), 525-535.

Kuzmanović, D. \& Pavlović Babić, D. (2011). Pristupi procenjivanju obrazovnih postignuća učenika: Kritički osvrt [Approaches in appraisement student achievement: A critical review]. Zbornik Instituta za pedagoška istraživanja, 43(1), 63-85. DOI: 10.2298/ZIPI1101063K

Mandić, D. (2003). Didaktičko-informatičke inovacije u obrazovanju [Didactical-IT innovation in education]. Beograd: Mediagraf.

Matijević, M. (2005). Evaluacija u odgoju i obrazovanju [Evaluation in upbringingand education]. Pedagogijska istraživanja, 2(2), 279-298.

Matijević, M. \& Topolovčan, T. (2017). Multimedijska didaktika [Multimedia didactics].Zagreb: Školskaknjiga.

Nacionalni prosvetni savet (2011). Obrazovanje u Srbiji: Kako do boljih rezultata [Education in Serbia: How to the better results]. Retrieved April 6, 2015 from http://www.cipcentar.org/i_roditelji_se_pitajy/PDF/ strategija/PRAVCI\%20RAZVOJA.pdf

Nadrljanski, Đ. \& Nadrljanski, M. (2008). Digitalni mediji - obrazovni softver [Digital media - educational software]. Sombor: Pedagoški fakultet u Somboru. 
Pedagoški leksikon [Pedagogical lexicon ] (1996). Beograd: Zavod za udžbenike i nastavna sredstva.

Radosav, D. (2005). Obrazovni računarski softver $i$ autorski sistemi [Educational computer software and author's systems]. Zrenjanin: Tehnički fakultet „Mihajlo Pupin” u Zrenjaninu.

Stanković, Z. (2005). Primena nastave na više nivoa složenosti multimedijalnim pristupom [Application of teaching at several levels of complexity with the multimedia approach]. Niš: Filozofski fakultet u Nišu; Prosveta.

Stanković, Z. \& Blazič, M. (2015). Didactical model of instruction based on the application of educational software. Didactica Slovenica. 30(1), 21-45.

\section{ELEKTRONSKA EVALUACIJA U RAZREDNOJ NASTAVI: DOKIMOLOŠKA VREDNOST OBRAZOVNOG SOFTVERA}

Kao posledica ekspanzije informatičke ere, u poslednjoj deceniji je primetan fokus na razvoj $i$ primenu informaciono-komunikacione tehnologije u obrazovanju, kojom se zahvaljujući njenom ubrzanom razvoju obeležava era elektronskog obrazovanja. Cilj elektronskog obrazovanja zapravo predstavlja modernizaciju nastavnog procesa, koja će nastavnicima omogućiti redukciju nastavnih obaveza, jednostavniju pripremu i izvođenje nastave kao i proveru znanja učenika, koja sa elektronskom platformom postaje važna komponenta multimedijalnog pristupa nastavi. Osnovni cilj ovog rada je da široj pedagoškoj stručnoj i naučnoj javnosti skrene pažnju, i ukaže na širi spektar mogućnosti koje pruža ovaj vid evaluacije u nastavnom procesu, $i$ to već na nivou razredne nastave. $U$ tom smislu, u radu se pored teorijskih razmatranja prezentuju i stečena iskustva iz prakse, nastala implementacijom dokimoloških potencijala kreiranog obrazovnog softvera, kao i iskustva upotrebe savremene obrazovne tehnologije.

Ključne reči: kompjuterska nastava, obrazovni softver, testovi znanja, elektronsko ocenjivanje, elektronska evaluacija. 